Article

\title{
Cross-Laminated Secondary Timber: Experimental Testing and Modelling the Effect of Defects and Reduced Feedstock Properties
}

\author{
Colin M. Rose ${ }^{1, * \mathbb{C}}$, Dan Bergsagel ${ }^{2}$, Thibault Dufresne ${ }^{3}$, Evi Unubreme ${ }^{3}$, Tianyao Lyu ${ }^{3}$, \\ Philippe Duffour ${ }^{3}\left({ }^{-}\right.$and Julia A. Stegemann ${ }^{3}(1)$ \\ 1 Department of Civil, Environmental \& Geomatic Engineering, Centre for Urban Sustainability and \\ Resilience, University College London, Gower Street, London WC1E 6BT, UK \\ 2 Scale Rule CIC, White Collar Factory, 1 Old Street Yard, London EC1Y 8AF, UK; dan@scalerule.org \\ 3 Department of Civil, Environmental \& Geomatic Engineering, Centre for Resource Efficiency \& the \\ Environment, University College London, Gower Street, London WC1E 6BT, UK; \\ dufresne.thibault@gmail.com (T.D.); evi.unubreme.14@ucl.ac.uk (E.U.); \\ tianyao.lyu.14@alumni.ucl.ac.uk (T.L.); p.duffour@ucl.ac.uk (P.D.); j.stegemann@ucl.ac.uk (J.A.S.) \\ * Correspondence: colin.rose.13@ucl.ac.uk; Tel.: +44-773-647-5214
}

Received: 31 August 2018; Accepted: 6 November 2018; Published: 9 November 2018

\begin{abstract}
The construction industry creates significant volumes of waste timber, much of which has residual quality and value that dissipates in conventional waste management. This research explored the novel concept of reusing secondary timber as feedstock for cross-laminated timber (CLT). If cross-laminated secondary timber (CLST) can replace conventional CLT, structural steel and reinforced concrete in some applications, this constitutes upcycling to displace materials of greater environmental impacts. The fabrication process and mechanical properties of CLST were tested in small-scale laboratory experiments, which showed no significant difference between the compression stiffness and strength of CLST and a control. Finite element modelling suggested that typical minor defects in secondary timber have only a small effect on CLST panel stiffness in compression and bending. Mechanically Jointed Beams Theory calculations to examine the potential impacts of secondary timber ageing on CLST panels found that this has little effect on compression stiffness if only the crosswise lamellae are replaced. Since use of secondary timber to make CLST has a more significant effect on bending stiffness, effective combinations of primary and secondary timber and their appropriate structural applications are proposed. The article concludes with open research questions to advance this concept towards commercial application.
\end{abstract}

Keywords: mass timber; lumber; waste wood; re-use and recycling; circular economy; off-site manufacture; building materials; construction and demolition waste; C\&D; end-of-waste

\section{Introduction}

The timber in existing building stocks represents a significant stockpile, with estimates in the range of 2.4-4.0 tonnes per capita [1,2]; in some countries, it is a greater quantity than the stock in forests managed for harvesting [3]. Upon building demolition, the cascading principles that form the basis of a circular economy [4,5] dictate that the resulting timber arisings should be reused [6-8], with minimised processing and loss of performance, to maximise their useful lifespan $[9,10]$ and maintain storage of sequestered carbon [11]. The greatest opportunities for long-term use in the built environment lie in structural applications as they have the longest lifespan [12].

However, direct reuse of timber is often impractical, for reasons including the fact that buildings are rarely designed with deconstruction and reclamation in mind [13,14]. Conventional recycling 
involves chipping timber and downcycling it into products such as particleboard and animal bedding, which achieves reliable supply and fitness for purpose, but with a considerable loss of performance and value; the recycled products are relatively short-lived and represent the final material use before incineration or disposal. Any reclaimed whole members that reach salvage yards tend towards shorter usable lengths and smaller effective sections. They may retain their mechanical characteristics [15], but are typically sold 'as seen' and without warranties, failing to provide certainty over supply and fitness for purpose, which restricts demand from mainstream construction [16].

Improving the supply of secondary timber to the construction industry could mitigate future risks, including increased competition for the use of land [17], price rises if timber supply is curtailed while demand rises [18], and future planning requirements, contractual obligations and regulation of whole-life greenhouse gas (GHG) emissions [19-23]. However, to capitalise on residual timber performance, there is a need for new processes that upcycle secondary timber, and recertify the resulting products to meet mainstream construction industry requirements [16,24].

This research proposed to exploit secondary timber as a feedstock for cross-laminated timber (CLT). The use of CLT has grown considerably in recent years; its advantages are well understood in academia, and it is gaining acceptance across industry [25]. Production capacity is rising, with Austria and Germany reporting 20\% year on year increases [26] and double-digit annual growth rates expected over the next decade [27]. The manufacture of CLT panels from variable feedstock in crosswise laminations minimises the detrimental influence of natural defects in individual boards of primary timber [28,29], and the same effect could be expected with defects arising from previous use of secondary timber. Laminated timber products also provide an opportunity to control the location of higher-grade timber in the engineered section to maximise structural benefit. Glulam standard BS EN 14080:2013 [30] already endorses production of structurally efficient sections from variable-quality wood, with stiffer and stronger timber at the extremities of the section, and weaker timber at the neutral axis, the function of the latter being primarily to increase the second moment of inertia by separating the outer lamellae. Based on Mechanically Jointed Beams Theory (MJBT, also known as the Gamma Method; Eurocode 5 [31,32]), a similar approach can be seen for CLT products, for which typical current European practice for strength and stiffness calculations largely disregards the contributions of the lamellae crosswise to the load application, e.g., horizontally oriented lamellae in a vertical compression element (wall), or lamellae oriented orthogonally to the span in a bending element (floor) [33].

Mining cities' existing timber stocks could enable greater self-sufficiency of cities in managing their construction and demolition waste (e.g., [34]) and help to localise CLT supply chains [35]. For example, as the UK has little forest cover (12\% of total land area, compared to $47 \%$ in Austria [36]), CLT, in particular, is imported to the UK from Austria and other parts of Europe. On the other hand, the timber fraction of UK construction and demolition waste is estimated at 0.9-5.0 Mtpa [37-40], of which something in the region of $55-75 \%$ is solid wood [37,39], and a growing proportion of this waste is exported for energy generation in Europe [38,39,41]. Using secondary timber stocks would contribute to policy goals: fostering a more circular economy with new employment in manufacturing [42] and reindustrialisation of the European (and British) economy [43-45], and production of net negative- or low-carbon building components. The lifespan at high value of timber in a circular economy could be further extended by designing the cross-laminated secondary timber (CLST) panels for deconstruction and reuse [46]. If CLST can replace conventional CLT, structural steel and reinforced concrete in some applications, this is enhancement of the performance of waste: upcycling into a new closed loop.

Timber for different structural uses is graded based on its tree species, origin, strength-reducing characteristics and geometrical characteristics [47-50]. CLT is typically made from Norway spruce, and common strength classes are C24, C18 and C16 [51]. However, there is growing interest in and research on use of locally abundant, under-utilised timber resources for which there are no established structural properties as feedstocks for CLT [52]. Examples include the use of Sitka spruce in Scotland [53,54] and Ireland [55]; Italian marine pine in Sardinia [28,56]; European beech in 
Germany and Switzerland [57-59]; large-leaf beech [60], Southern pine [61,62], hybrid poplar [63] and tulipwood [64,65] in North America; poplar [66] and eucalyptus [67] in China; and Japanese cedar [68]. Investment in a new CLT and glulam plant in Alabama that exploits local Southern pine [69] suggests that alternative feedstocks to those used in typical European CLT production can become economically viable if abundant local materials are used.

Although European Standard BS EN 16351:2015 [70] does not allow used wood in CLT as a precaution, it has also previously been suggested that secondary timber could be used to produce engineered wood products [71-74]. Researchers at the University of Utah with industry partners investigated the manufacture of interlocking 'ICLT' without adhesives or fasteners [75]. Their work considered sourcing the timber from existing buildings, but they chose instead to explore pilot manufacture and mechanical testing of ICLT using standing trees that have been affected by pine bark beetle [76]. Thus, the concept of CLST has not yet been tested.

For certifiable mass production of CLT, consistency of supply of raw materials and raw material quality is crucial. However, as a natural material, the properties of primary timber are variable, and the extent of variability can be greater between two members sawn from the same tree than from two different species [77]. Strength classes are based on characteristic properties and individual members may well fall short of the characteristic values; BS EN 16351:2015 [70] makes allowance for this by permitting deviation of up to $35 \%$ from the declared strength parallel to the grain in $10 \%$ of boards in any given lamella. Despite this acceptance of uncertainty, achieving equivalent levels of confidence in secondary timber requires an understanding of how ageing and use affect both its characteristics and the variability of these characteristics.

Natural ageing results from biological, chemical, mechanical, thermal, water and other weathering effects [78]. When 'stored' in use in a building's structure, timber is typically protected from weathering, and moisture content should be below $20 \%$, such that it is largely protected from biological degradation. Softwoods, which make up the majority of secondary timber, may benefit from increasing cellulose crystallisation for the first few hundred years of life [79,80], leading to increases in density, hardness, dimensional stability, tensile strength, and Young's modulus (the ratio of elastic stress and corresponding strain, also known as the Modulus of Elasticity, MOE) [81]. However, two recent review papers $[82,83]$ found that there has been no overall consensus on the effect of natural ageing on strength, stiffness and other physical properties of various species of timber. Ageing during use inside a building, e.g., through fluctuations in temperature, humidity or the effects of ultraviolet radiation, may affect timber's mechanical properties, but findings are often ambiguous, and could result from other factors [83-87]. Surface characteristics of timber change with time [83] and, for use in CLT, the faces of secondary boards would need to be planed to provide a good surface for durable bonding as well as to produce consistent thicknesses.

It is well established that timber can carry substantially greater loads over a short period of time than for long durations of loading; Fridley et al. [88] present a history of research investigating this 'duration of load' (DOL) effect going back to the eighteenth century. Much of the research into creep-rupture, the failure mode attributed to the DOL effect, uses results of impact testing and short- and long-term loading to estimate expected times until failure for loading at a given stress ratio (i.e., a proportion of assumed short-term strength [89]). Higher moisture content is known to produce a shorter time to failure, while cyclical changes in moisture content further accelerate creep and reduce time to creep-failure [90]. Since at least the nineteenth century, it has been understood that timber structures intended for long life should be designed with a safety factor such that only one-half to two-thirds of the material's short-term strength is relied upon [88]. The effects of DOL and moisture content have long been incorporated into design standards for timber building structures; e.g., Eurocode 5 [31] sets out strength modification factors ranging from 0.50 for 'permanent' loading ( $>10$ years) in climatic conditions that may lead to moisture content $>20 \%$; 0.60 for permanent loading where moisture content is $<20 \%$; to 1.10 for instantaneous loading for moisture content $<20 \%$. 
It is important to note that DOL effects are particularly significant in the short- and medium-terms. In the long-term, a difference of double or triple the anticipated load duration affects the load capacity by only a few percentage points [89]. The major reduction in load capacity predicted by DOL modelling occurs over the first few years-and certainly within a period of time in the order of a normal building lifespan of, say, 50 years-with further degradation beyond that time found to be minimal in most DOL research $[89,91,92]$. This seems to bear out the observation that many very old timber structures remain standing. Arguably, therefore, secondary use of timber simply extends its anticipated load duration and could be expected to produce only minor reduction in load capacity, compared to the strength modification factors taken into account in its first use.

Nevertheless, uncertainties remain. Timber that has been exposed to high and especially to fluctuating moisture content, for instance through external use, is likely to have experienced significant strength loss and is unlikely to be suitable for reuse in a structural application. Evidence suggests that large solid timber members used internally do not undergo large moisture fluctuations [86], but this may not always hold true. Repeated loading may have caused fatigue damage to have accumulated in secondary timber that cannot be perceived [89]. The stress ratio at which loss of strength becomes permanent appears to vary widely depending on timber species and testing conditions, with an average perhaps in the region of 0.40 [92]. On the other hand, different conclusions arise from the extensive work by the USDA Forest Products Laboratory on the structural properties and grading of North American secondary timber [15,93-104]. They acknowledge that 'overloading' can degrade timber, but their testing indicates that MOE and bending strength appear to be unaffected by ageing and previous load history [15], and that reductions in strength arise from observable macro-level defects, such as nail holes, rather than from the molecular structure of aged timber. They therefore recommend regrading before reuse but conclude that wholesale visual downgrading is currently too conservative. The group consider some reuse options for different species of reclaimed timber $[105,106]$, including nail-laminated posts [103]. They were able to conclude that the tested material has potential for reuse in this structural application, but have not extended their investigation into CLT.

On this basis, preliminary research to explore the technical feasibility of using secondary timber to produce CLST was conducted. The specific objectives were:

1. To make CLST and cross-laminated primary timber (CLPT) at small-scale;

2. To examine and compare the compressive and bending strengths of the CLST and CLPT prepared in (1) using standard laboratory tests;

3. To examine the potential effects of manmade defects on properties of CLST using finite element modelling (FEM);

4. To examine the potential effects of reduced properties of individual lamellae (potentially arising from ageing, history of loading and climatic conditions), on the effective overall section properties of CLST using MJBT;

5. To make recommendations for further research necessary to advance this concept to pilot-scale and commercial application.

Laboratory testing, FEM and MJBT were undertaken as complementary techniques to examine the potential effects of previous use of secondary timber feedstock on CLST, whereby the modelling techniques enabled additional preliminary investigations without the need for further physical testing. FEM was used to model specific defects, whereas MJBT is a relatively simple calculation that allowed the possible overall effect of feedstock ageing to be examined without undertaking extensive FEM.

\section{Materials and Methods}

\subsection{Timber}

Mixed-species softwood boards collected by a reuse enterprise [107] from construction and demolition sites across London over a period of 2-3 years were surveyed for defects (Table 1) and 
used to make CLST in the UCL laboratory. This secondary timber had been stored horizontally indoors at $\sim 65 \%$ relative humidity and had a moisture content of $13.7 \pm 0.8 \%$ dry mass, based on testing in triplicate according to BS EN 13183-1:2002 [108]. Board lengths used for CLST ranged from 300-900 $\mathrm{mm}$; board cross-sections varied from $90-170 \mathrm{~mm}$ in width and $20-45 \mathrm{~mm}$ in thickness.

Table 1. Survey of defects in secondary timber-categories and findings.

\begin{tabular}{|c|c|c|c|}
\hline Defect & Description & $\begin{array}{l}\text { Similar Natural Defect } \\
\text { and Reference }\end{array}$ & $\begin{array}{l}\text { Number per } \\
\text { Linear Metre }\end{array}$ \\
\hline Small nail holes & $\begin{array}{l}<2 \text { mm diameter, not all the } \\
\text { way through member }\end{array}$ & $\begin{array}{l}\text { Worm hole/pin hole; } \\
\text { allowed in [49] }\end{array}$ & 6.8 \\
\hline Large nail holes & $\begin{array}{l}\text { 2-4 mm diameter, not all the } \\
\text { way through member }\end{array}$ & $\begin{array}{l}\text { Small knot hole; } \\
\text { allowed in [70] }\end{array}$ & 3.0 \\
\hline Screw holes & $\begin{array}{l}<6 \mathrm{~mm} \text { diameter, not all the } \\
\text { way through member }\end{array}$ & $\begin{array}{l}\text { Small knot hole; } \\
\text { allowed in [70] }\end{array}$ & 0.8 \\
\hline Through screw holes & $\begin{array}{c}<6 \mathrm{~mm} \text { diameter, all the way } \\
\text { through member }\end{array}$ & $\begin{array}{l}\text { Small knot hole; } \\
\text { allowed in [70] }\end{array}$ & 0.6 \\
\hline Bolt holes & $\begin{array}{l}\text { 6-10 mm diameter, all the } \\
\text { way through member }\end{array}$ & Large knot hole; [49] & 0.5 \\
\hline Notches & $\begin{array}{c}\text { Rectangular cut-outs } \\
\text { nominally } 20 \times 40 \mathrm{~mm}\end{array}$ & $\begin{array}{l}\text { Excessively large knot } \\
\text { hole; rejected in [49] }\end{array}$ & 0.0 \\
\hline Small knots & Disregarded if $<6 \mathrm{~mm}$ & [70] & $\mathrm{n} / \mathrm{a}$ \\
\hline Large knots & $>6 \mathrm{~mm}$ diameter & {$[49,70]$} & 2.8 \\
\hline
\end{tabular}

The survey of 30 boards with a total length of $43.8 \mathrm{~m}$ considered manmade holes that would be considered natural knots and 'abnormal defects' in BS 4978:2007 [49]. With reference to visual grading rules for softwood (BS 4978:2007 [49]), defects were grouped according to their cause and the natural defects that they resemble (Figure 1), for use in the FEM. Manmade holes had been formed by nails, screws and bolts (counted regardless of whether the fixing was still present), and two members had jointing notches. BS 4978:2007 [49] allows abnormal defects if their effect is 'obviously less than that caused by the defects admitted by the grade'. A further four members were rejected because excessive distortion meant that they could not be worked with the machinery available. No members exhibiting wet rot were found.
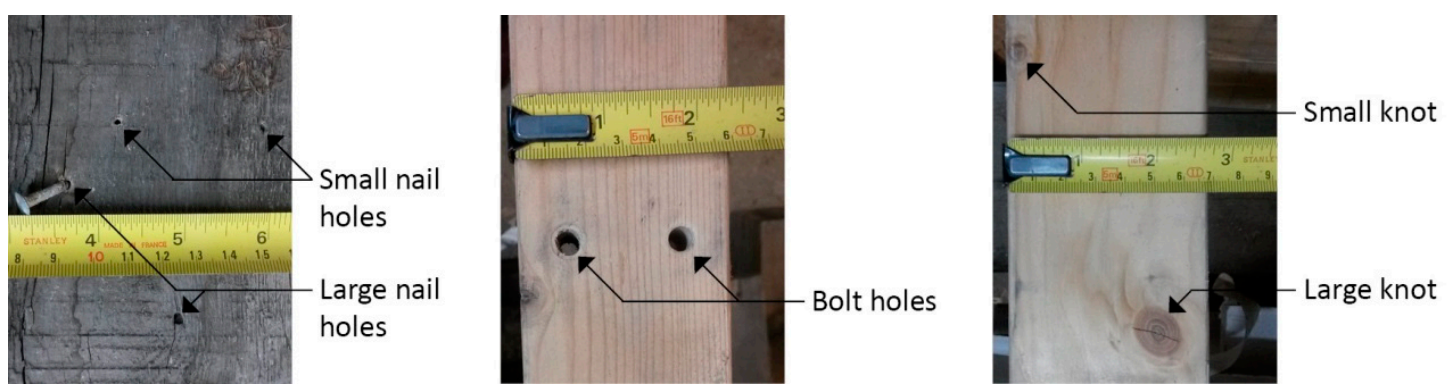

Figure 1. Timber defect survey—nail holes, bolt holes and knots.

To be able to observe differences between CLST and CLPT, and avoid confounding these with production quality differences arising from the use of laboratory woodworking equipment versus commercial CLT factory equipment, CLPT was also made in the UCL laboratory, with new kiln-dried Scandinavian pine from a timber merchant (Travis Perkins Redwood Planed Timber). The moisture content of the purchased timber was measured to be $12.5 \pm 0.8 \%$ dry mass. The $2400 \mathrm{~mm}$ boards had a cross-section of $94 \times 20 \mathrm{~mm}$. 


\subsection{Preparation of Cross-Laminated Secondary and Primary Timber}

Both the secondary and primary timber boards were trimmed to a uniform cross-section of $80 \times 17 \mathrm{~mm}$. As equipment for machine grading or a trained visual grader were not available, all timber was informally graded based on the presence and size of knots, distortion of members, and slope of grain, with reference to BS 4978:2007 [49]. Arrises and wane were removed in the trimming process. In each case, the best grade was reserved for use in the outer lamellae.

Preparation of the CLST and CLPT mirrored the commercial CLT fabrication process (e.g., [109]) as closely as possible. A commercial single-component polyurethane (PUR) adhesive manufactured by Kingfisher was used to glue the timber into lengths, lamellae and panels. Boards were finger-jointed flatwise using a CNC machine with a cutter bit parallel to the grain (Figure 2a), which were then glued and clamped. After curing for $24 \mathrm{~h}$, boards were cut to length and bonded edge-to-edge (again using customised clamps) to form lamellae (Figure 2b). The cured lamellae were then laminated with adhesive in a customised mould, with each lamella perpendicular to the next. The adhesive spread rate was around $105 \mathrm{~g} / \mathrm{m}^{2}$. A hydraulic press (Figure 2c) was used to apply a uniform compressive stress of $0.05 \mathrm{MPa}$, which is considered appropriate for PUR [51]. Due to the limitations of the press, the panels had overall dimensions of $820 \times 320 \mathrm{~mm}$. One 5-lamella (85 mm thick) panel (Figure $2 \mathrm{~d}$ ), for use in compression testing, and one 3-lamella (51 mm thick), for use in bending tests, were fabricated and cut to produce test specimens.

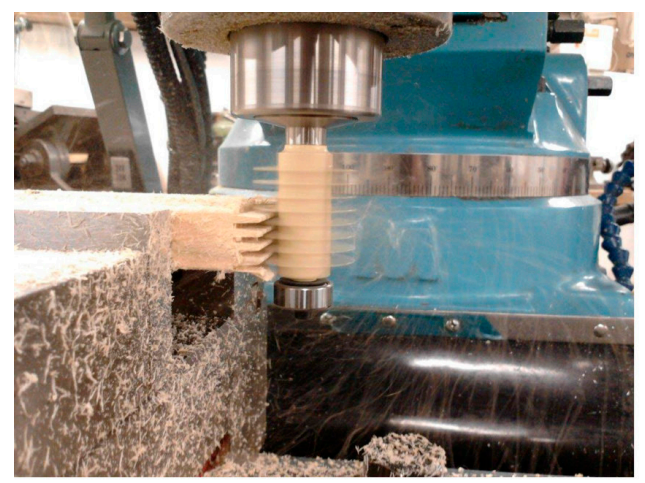

(a)

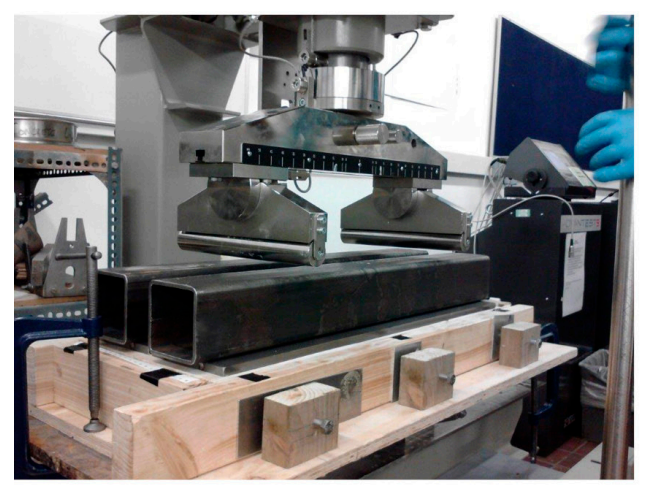

(c)

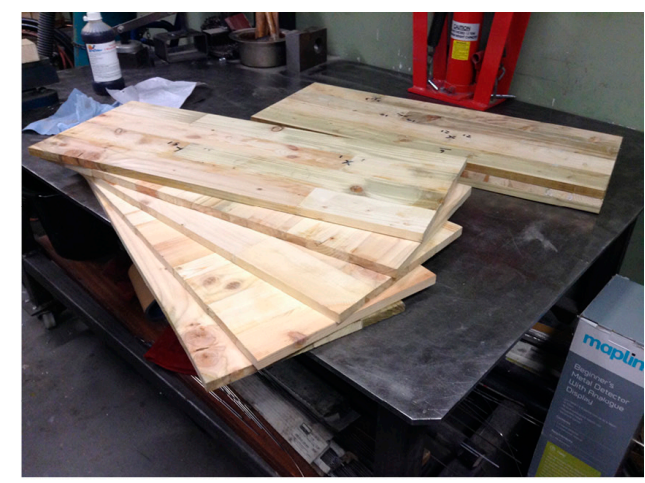

(b)

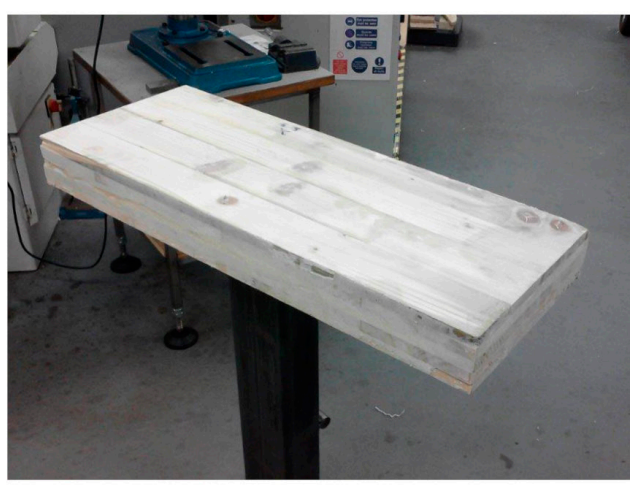

(d)

Figure 2. Cross-laminated secondary timber (CLST) production in the laboratory: (a) finger-jointing; (b) lamellae from secondary timber; (c) hydraulic pressing of lamellae; (d) 5-lamella CLST specimen.

\subsection{Laboratory Testing of Cross-Laminated Secondary and Primary Timber in Compression and Bending}

Unconfined compressive strength (UCS) was measured in triplicate based on BS EN 408:2010 [110], using an Advantest 9 control console fitted with a compression frame of capacity up to $2000 \mathrm{kN}$. Specimens of $85 \times 85 \times 85 \mathrm{~mm}$ were uniformly loaded on all three axes (Figure 3 ). Deflection was monitored using a linear variable displacement transducer (LVDT) with maximum travel distance 
of $50 \mathrm{~mm}$. The load was applied at a steady rate of $4.25 \times 10^{-3} \mathrm{~mm} / \mathrm{s}$ in the $\times$ and $Y$ directions, and $0.425 \mathrm{~mm} / \mathrm{s}$ in the Z direction, until measurement of the UCS at failure (BS EN 408:2010 [110]).

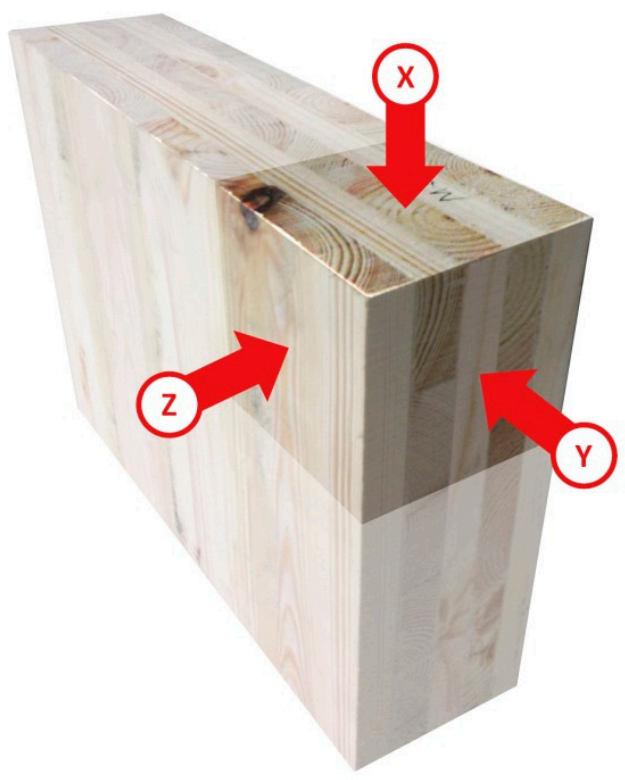

$\mathrm{X}$ ) Loading on axis parallel to the grain direction of the outermost lamellae

Y) Loading on axis orthogonal to the grain

direction of the outermost lamellae

Z) Loading on axis perpendicular to the plane of the CLT

Figure 3. Different loading axes for compression testing (labelling according to BS EN 16351:2015 [70]).

CLT specimens were subjected to destructive four-point bending tests in accordance with BS EN 408:2010 [110], again in triplicate. To maintain the specified span-to-depth $(L / d)$ ratio of 15:1 despite limitations on specimen length produced in the UCL laboratory, specimen depth and width were set to $51 \mathrm{~mm}$ for a span of $765 \mathrm{~mm}$. An Advantest 9 control console fitted with a flexural frame with loading capacity up to $500 \mathrm{kN}$ was used. The two loading heads were located at the third points (i.e., a distance of $255 \mathrm{~mm}$ from each end support). The specimens were loaded symmetrically parallel to the grain direction of the outermost lamellae, i.e., out-of-plane bending of the panel's $X$-axis around the $Y$-axis in Figure 3, at a loading rate of $25.5 \mu \mathrm{m} / \mathrm{s}$, until measurement of the bending strength (modulus of rupture, MOR) at failure. The deflections were measured using an LVDT positioned centrally under the loading head and the corresponding loads were used to calculate the Local MOE in bending.

\subsection{Finite Element Modelling of Effects of Defects on Cross-Laminated Secondary Timber Modulus of Elasticity}

FEM was used to estimate and compare the mechanical properties of CLST containing various timber defects. CLST behaviour in compression and bending tests to BS EN 408:2010 [110] was simulated using ABAQUS to determine the MOE of CLST components with and without defects. Cubic elements (hexahedral C3D8R) with orthotropic material properties were used. The mesh contained four to five elements through the smaller thickness which was deemed sufficient for convergence.

Timber structures are designed elastically because the material fails in a brittle manner [111]. Therefore, only the elastic behaviour of CLST was modelled, in keeping with other methodologies for modelling wood as a linear orthotropic material using ABAQUS [112] and COMSOL [113]. The timber properties were arbitrarily based on the elastic properties of Norway spruce at $12 \%$ dry mass moisture content [114].

To model the adhesive component, a 'cohesive behaviour' was added as a contact property between each of the lamellae. The normal and tangential elastic parameters of the adhesive, $k_{n}$ and $k_{t}$, were obtained using the following equations and adhesive properties from the literature $[113,115]$ :

$$
k_{n}=\frac{E_{a d}\left(1-v_{a d}\right)}{t_{a d}\left(1+v_{a d}\right)\left(1-2 v_{a d}\right)}
$$




$$
k_{t}=\frac{G_{a d}}{t_{a d}}
$$

where, Poisson's ratio, $v_{a d}=0.37, \mathrm{MOE}, E_{a d}=4 \mathrm{GPa}$, Shear modulus, $G_{a d}=1.54 \mathrm{GPa}$, Bond line thickness, $t_{a d}=0.5 \mathrm{~mm}$.

To model their effects on the MOE of a CLST element, defects were introduced in the FEM at their maximum sizes in the defect survey (Table 1), with configurations as shown in Table 2 (columns $2-5$ ). Defects were placed such that those on neighbouring lamellae would not coincide, except for Run J, and the random defect positioning in Runs G, H and I. The notch (runs I and J) was modelled to examine the effect of replacing three randomly placed small defects in each lamella with a single large defect of the same volume in each lamella. Hexahedral meshing was used to model different geometries of the defects, i.e., cylindrical knots, nail, screw and bolt holes, rectangular notches. The 'composite layup' module of ABAQUS allowed the grain direction of knots to be altered relative to the board grain direction (Runs $\mathrm{L}$ and $\mathrm{N}$ ).

Out-of-plane bending of the panel's $X$-axis around the $Y$-axis was modelled for a panel of the same dimensions as the laboratory bending test (Table 3). Initially, a single large hole was modelled at the centre of the span, and then shifted off-centre. Defects of the size and number identified in the survey were then introduced into each board at random locations along their length based on the typical dimensions and spacing observed in the survey. Finally, defects were concentrated at the centre of the span.

Table 2. Configuration of CLST with manmade (runs A-J) and natural (runs K-N) defects in $85 \mathrm{~mm}$ cubes with five lamellae for finite element modelling of compression tests.

\begin{tabular}{|c|c|c|c|c|c|}
\hline Run & Defect Type & $\begin{array}{c}\text { Defect } \\
\text { Diameter } \times \text { Depth }\end{array}$ & $\begin{array}{l}\text { Distance from Sides } \\
\text { of Specimen }(\mathrm{mm})\end{array}$ & $\begin{array}{l}\text { No. of } \\
\text { Defects } \\
\text { per Lamella }\end{array}$ & $\begin{array}{l}\text { Resulting Normalised MOE } \\
\text { of CLST in Compression } \\
\text { on Y-Axis (MPa) }\end{array}$ \\
\hline A & None & $\mathrm{n} / \mathrm{a}$ & $\mathrm{n} / \mathrm{a}$ & 0 & 1.00 \\
\hline B & Small nail hole & $2 \times 10$ & $60 \times 20^{a}$ & 1 & 0.99 \\
\hline $\mathrm{C}$ & Large nail hole & $4 \times 10$ & $60 \times 20^{a}$ & 1 & 0.99 \\
\hline $\mathrm{D}$ & Screw hole & $6 \times 10$ & $60 \times 20^{a}$ & 1 & 0.98 \\
\hline $\mathrm{E}$ & $\begin{array}{c}\text { Through screw } \\
\text { hole }\end{array}$ & $6 \times 17^{b}$ & $30 \times 30^{a}$ & 1 & 0.97 \\
\hline $\mathrm{F}$ & Bolt hole & $10 \times 17^{b}$ & $30 \times 30^{a}$ & 1 & 0.96 \\
\hline G & Mixed & $\begin{array}{l}2 \times 10 \\
4 \times 10 \\
6 \times 10\end{array}$ & Random & 3 & 0.96 \\
\hline $\mathrm{H}$ & Bolt hole & $10 \times 17^{b}$ & Random & 10 & 0.84 \\
\hline I & Notch & $20 \times 40 \times 17^{b}$ & Random & 1 & 0.81 \\
\hline $\mathrm{J}$ & Notch & $20 \times 40 \times 17^{b}$ & $\begin{array}{c}60 \times 40 \\
\text { (all same spot) }\end{array}$ & 1 & 0.79 \\
\hline K & $\begin{array}{l}\text { Small knot at } \\
90^{\circ} \text { to grain }\end{array}$ & $12 \times 17^{b}$ & $60 \times 20^{a}$ & 1 & 0.94 \\
\hline L & $\begin{array}{l}\text { Small knot at } \\
45^{\circ} \text { to grain }\end{array}$ & $12 \times 17^{b}$ & $60 \times 20^{a}$ & 1 & 0.96 \\
\hline M & $\begin{array}{l}\text { Large knot at } \\
90^{\circ} \text { to grain }\end{array}$ & $24 \times 17^{b}$ & $60 \times 20^{a}$ & 1 & 0.87 \\
\hline $\mathrm{N}$ & $\begin{array}{l}\text { Large knot at } \\
45^{\circ} \text { to grain }\end{array}$ & $24 \times 17^{b}$ & $60 \times 20^{a}$ & 1 & 0.87 \\
\hline
\end{tabular}


Table 3. Configuration of CLST with defects in $51 \times 51 \times 820 \mathrm{~mm}$ 3-lamella specimens for finite element modelling of bending tests.

\begin{tabular}{ccc}
\hline Run & Description a $^{\text {a }}$ & $\begin{array}{c}\text { Resulting Normalised MOE of } \\
\text { CLST in Bending (MPa) }\end{array}$ \\
\hline $\mathrm{P}$ & No defect & 1.00 \\
$\mathrm{Q}$ & Single large hole located at centre of span & 0.97 \\
$\mathrm{R}$ & Single large hole located off-centre of span & 0.98 \\
$\mathrm{~S}$ & Miscellaneous spread out holes & 0.99 \\
$\mathrm{~T}$ & Miscellaneous holes clustered at centre of span & 0.98 \\
\hline
\end{tabular}

a See Supplementary Material S1 for further details of model geometry and positions of defects.

\subsection{Mechanically Jointed Beams Theory Analysis of Effects of Lamella Properties on Cross-Laminated Secondary Timber Stiffness}

Use of FEM to examine defects was complemented by MJBT to examine the influence of reduced feedstock properties, which the existing literature suggests could come about from the effects of timber ageing, environmental conditions and the DOL effect. MJBT is widely used to calculate the overall bending stiffness of a built-up timber element, such as a timber I-joist, by considering the independent bending stiffness of its constituent components [31,32]. This is achieved by applying reductions in connection stiffness between the components to model the effects of fasteners, such as nails or glue, on the stiffness of the overall section. To calculate the overall bending stiffness of a CLT element instead of a built-up timber element, the crosswise lamellae can be treated as fasteners with reduced stiffness, without separate representation of the adhesive. A CLT element was thus considered as a set of independent longitudinal lamellae (in the $X$-axis) fixed to the other lamellae in the section by fasteners with stiffness $\gamma$, a function of the rolling shear stiffness of the intermediate crosswise lamellae [32]:

$$
\gamma=\frac{1}{1+\frac{\pi^{2} E_{0, x} t_{x}}{L_{r e f}^{2}} \frac{t_{y}}{G_{r, y}}},
$$

$E_{0, x}=$ MOE of the longitudinal lamellae, $t_{x}=$ thickness of outer longitudinal lamella, $G_{r, y}=$ rolling shear modulus for the intermediate crosswise lamella $=E_{0, y} / 160$ [31], $t_{y}=$ thickness of intermediate crosswise lamella, $L_{r e f}=$ effective length of test sample (equal to test sample length for a pinned compression element, or simply supported bending element).

MJBT was used to calculate a CLT element bending stiffness $(E I)_{C L T, e f f}$ in out-of-plane bending of its $X$-axis (i.e., around the $Y$-axis), which is a function of the MOE and thickness of the longitudinal lamellae, but also the MOE and thickness of the crosswise lamellae, and the length of the CLT element being considered:

$$
(E I)_{C L T, e f f}=\sum_{\substack{i=1 \\ i \text { odd }}}^{n}\left(E_{0, i} I_{i}+\gamma_{i} E_{o, i} b t_{i} y_{i}^{2}\right) ; n=3 \text { or } 5
$$

$I_{i}=$ second moment of area of each lamella, $n=b t_{i}{ }^{3} / 12, b=$ width of overall section, $y_{i}=$ distance of centre of lamella from overall section neutral axis.

MJBT was also used to calculate the CLT element compression stiffness $E_{C L T, x} k_{c}$ with loading in the $X$-axis:

$$
E_{C L T, x} k_{c}=\frac{\sum_{1 \leq i \leq n, i \text { odd }}\left(E_{0, x, i} b t_{i}\right)}{\sum_{i=1}^{n}\left(b t_{i}\right)} k_{c} ; n=3 \text { or } 5
$$

where $k_{c}$ is a factor to account for buckling effects using an $I_{\text {eff }}$ derived from $(E I)_{C L T, e f f} / E$ [31].

As expected, the CLT compression stiffness and bending stiffness are both linear in relation to lamella stiffness, if the stiffness of all lamellae is altered equally. However, the $k_{c}$ and $I_{\text {eff }}$ 
components are non-linear functions related to the length of the CLT element, and the thickness of the crosswise lamellae.

To examine the effect of lamellae with reduced MOE on overall CLT compression stiffness and bending stiffness, the variables in Equations (4) and (5) were varied as indicated in Table 4. The overall section thickness was the same for all runs, whether the CLT had 3 or 5 lamella. For Runs labelled " $\mathrm{C}$ ", the MOE of only the crosswise lamellae was reduced, using a range of values from $100 \% \mathrm{MOE}$ (11,000 MPa, based on C24) to 70\% MOE (7700 MPa); for Runs labelled "L + C", the MOEs of the longitudinal as well as crosswise lamellae were reduced in tandem, from $100 \% \mathrm{MOE}$ to $70 \% \mathrm{MOE}$.

Table 4. Configurations of cross-laminated timber for Mechanically Jointed Beams Theory calculations (overall section width, $b=85 \mathrm{~mm}$ and depth $d=85 \mathrm{~mm}$ ).

\begin{tabular}{|c|c|c|c|c|c|c|}
\hline \multirow{2}{*}{ Run } & \multirow{2}{*}{$\begin{array}{l}\text { Span-to-Depth } \\
\text { (L/d) Ratio }\end{array}$} & \multirow{2}{*}{$\begin{array}{l}\text { No. of Lamellae of } \\
\text { Equal Thickness }\end{array}$} & \multirow{2}{*}{$\begin{array}{c}\text { Lamella } \\
\text { Thickness, } \mathrm{t}(\mathrm{mm})\end{array}$} & \multicolumn{2}{|c|}{ Lamella MOE (MPa) } & \multirow{2}{*}{$\begin{array}{c}\text { Element } \\
\text { Length, L (mm) }\end{array}$} \\
\hline & & & & $\mathrm{E}_{0, \mathrm{x}}$ & $E_{0, y}$ & \\
\hline $10 / 3 / C$ & 10 & 3 & 28 & 11,000 & $11,000-7700$ & 850 \\
\hline $10 / 3 / L+C$ & 10 & 3 & 28 & $11,000-7700$ & $11,000-7700$ & 850 \\
\hline $10 / 5 / \mathrm{C}$ & 10 & 5 & 17 & 11,000 & $11,000-7700$ & 850 \\
\hline $10 / 5 / L+C$ & 10 & 5 & 17 & $11,000-7700$ & $11,000-7700$ & 850 \\
\hline $30 / 3 / \mathrm{C}$ & 30 & 3 & 28 & 11,000 & $11,000-7700$ & 2550 \\
\hline $30 / 3 / L+C$ & 30 & 3 & 28 & $11,000-7700$ & $11,000-7700$ & 2550 \\
\hline $30 / 5 / C$ & 30 & 5 & 17 & 11,000 & $11,000-7700$ & 2550 \\
\hline $30 / 5 / L+C$ & 30 & 5 & 17 & $11,000-7700$ & $11,000-7700$ & 2550 \\
\hline
\end{tabular}

\section{Results}

\subsection{Laboratory Testing of Cross-Laminated Secondary and Primary Timber in Compression and Bending}

The ranked results from the compression and bending experiments of the CLST have been plotted against those for the CLPT in Figure 4. It appears that the properties of both materials were similar in compression, but that the bending strength of the CLST was about only $60 \%$ of that of the CLPT, whereas the MOE in bending of the CLST was about double that of the CLPT.

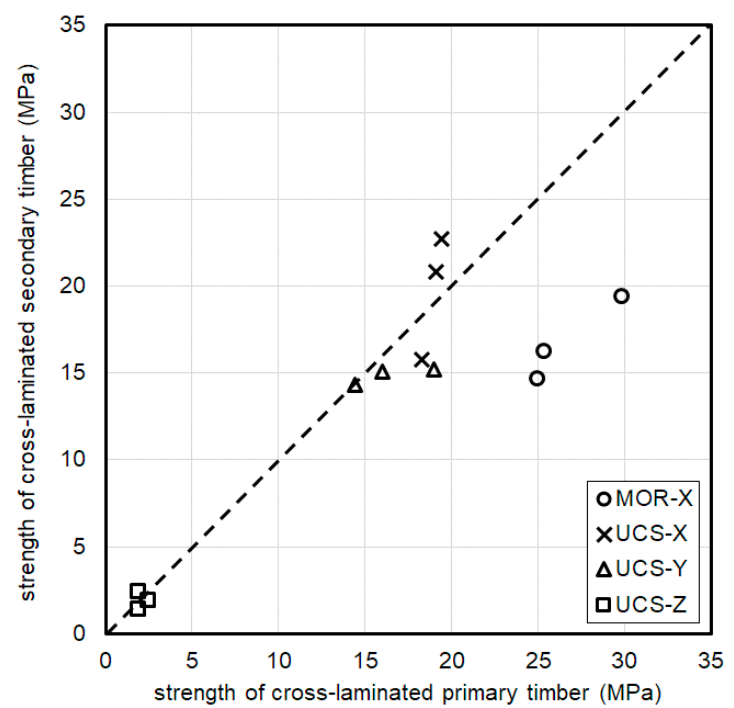

(a)

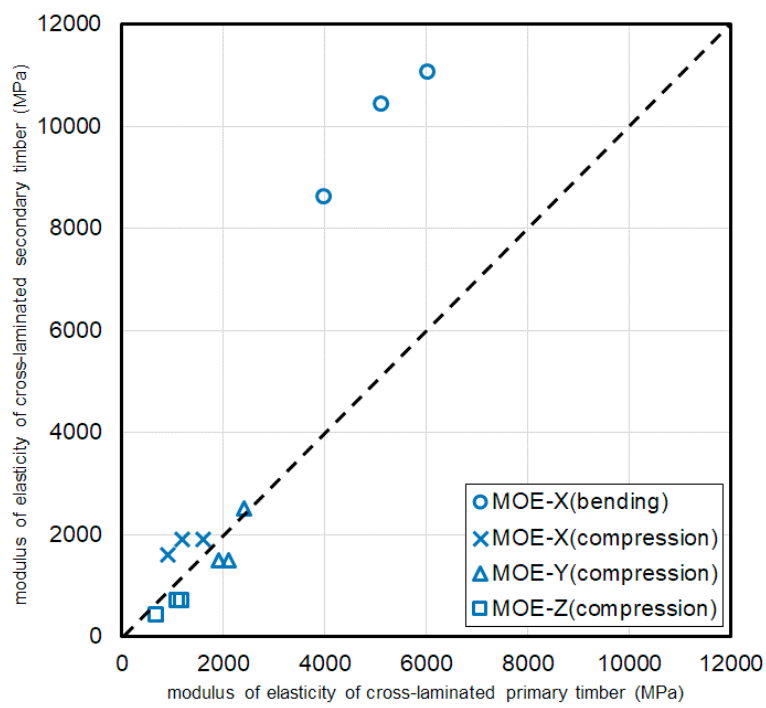

(b)

Figure 4. (a) Modulus of rupture (MOR), unconfined compressive strength (UCS), and (b) Modulus of Elasticity measurements for cross-laminated primary and secondary timber prepared in the laboratory.

There was some failure of adhesion between lamellae in both tests. In bending, failure largely resulted from tensile failure at finger joints (70\% across all specimens) and knots. 


\subsection{Finite Element Modelling of Effects of Defects on Cross-Laminated Secondary Timber Modulus of Elasticity}

MOEs estimated by FEM of specimens with defects are shown in column 6 of Table 2. As arbitrary timber properties were used for FEM in the absence of known values for secondary timber, the results in column 6 of Table 2 are expressed as reductions against a specimen without defects, rather than as absolute values. It appears that:

- Configurations with defects $\leq 12 \mathrm{~mm}$ in diameter and up to three defects (nail, screw and bolt holes, and small knots) in all lamellae resulted in $<6 \%$ degradation of the MOE of CLST in compression, whereas larger notches and knots, and larger numbers of defects introduced up to $21 \%$ degradation.

- The effect of defects that extended all the way through a board was only slightly more than that of those that did not.

- The MOE in compression of many bolt holes was $4 \%$ greater than that of a single notch with the same volume, i.e., several smaller defects appear to be less damaging than a single large defect.

- Knots perpendicular to the direction of the grain have a slightly greater effect on MOE than knots at $45^{\circ}$.

Introducing manmade defects appeared to have little impact on MOE in bending (Table 3). The largest degradation $(2.7 \%)$ was produced by a single large defect at the centre of the span. A typical quantity of smaller defects, spread out along the length of boards, created a degradation of $0.9 \%$, and when the same defects were concentrated on the centre of the span, degradation was $1.6 \%$. As with the compression tests, defect volume concentrated in one area is more damaging to MOE than the same volume distributed over several defects.

\subsection{Mechanically Jointed Beams Theory Analysis of Effects of Lamella Properties on Cross-Laminated Secondary Timber Stiffness}

As with the FEM, results are expressed as reductions rather than absolute values. Figure 5 plots the compressive stiffness for different configurations of CLST elements, whereby the compression stiffness values, $E_{C L T, x} k_{c}$, for each of the configurations have been normalised by dividing them by that calculated for 3-lamella CLT with no reduction in feedstock MOE (100\% MOE). These normalised values are indicated by the symbol ' $\sim$ ', as $\sim E_{C L T, x} k_{c}$. Over the range of up to $30 \%$ feedstock MOE reductions investigated for CLST elements with the same overall thickness, it appears that:

- Reducing the feedstock MOE for both longitudinal and crosswise lamellae (" $\mathrm{L}+\mathrm{C}^{\prime \prime}$ ) leads to a maximum decrease in overall element compression stiffness of $30 \%$ (for a feedstock MOE reduction of $30 \%$ for all of 5 lamellae, with $L / d=30$ ).

- Reducing the feedstock MOE of only the crosswise lamellae ("C $\left.\mathrm{C}^{\prime}\right)$ leads to a maximum decrease in overall element compression stiffness of only $5.5 \%$.

- The compression stiffness of 3-lamella CLST is greater than that of 5-lamella CLPT and CLST with the same overall thickness, and this difference is more pronounced at a higher span-to-depth ratio.

- The compression stiffness of 3-lamella CLST exceeds that of 5-lamella CLPT for up to:

- $6 \%$ feedstock MOE reduction of both longitudinal and crosswise lamellae, and

- $30 \%$ feedstock reduction of only the crosswise lamellae. 


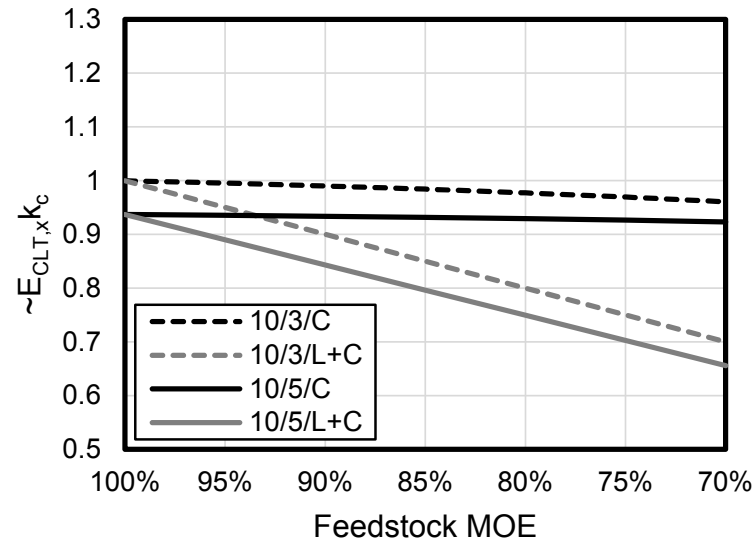

(a)

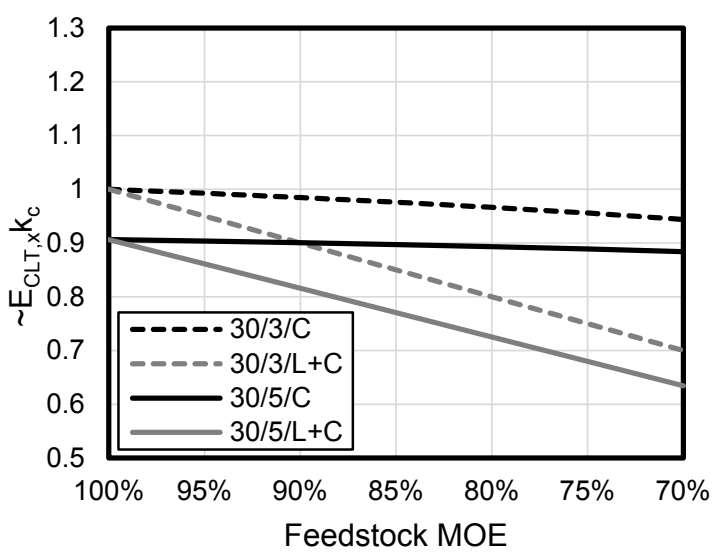

(b)

Figure 5. Normalised compression stiffness $\left(\sim E_{C L T, x} k_{c}\right)$ for 3- and 5-lamella cross-laminated secondary timber with varying feedstock modulus of elasticity (MOE) reductions, of the longitudinal (L) and/or crosswise (C) lamellae, with (a) span-to-depth ratio, $L / d=10$ and (b) $L / d=30$.

Figure 6 plots the normalised bending stiffness for different configurations of CLST elements. It appears that:

- Reducing the feedstock MOE for both longitudinal and crosswise lamellae leads to a maximum decrease in overall bending stiffness of 35\% (for a feedstock MOE reduction of $30 \%$ for all of either 3 or 5 lamellae, with $L / d=30$ ).

- Reducing the feedstock MOE of only the crosswise lamellae leads to a smaller reduction in overall CLST element bending stiffness, which is only $2.5 \%$ for the 5-lamella element with $L / d=30$, but up to $14 \%$ for that with $L / d=10$.

- Element span-to-depth ratio has an important impact on the results, with 5-lamella CLST having a greater bending stiffness than 3-lamella CLST for $L / d=10$, and vice versa for $L / d=30$.

- For $L / d=10$, the bending stiffness of 3-lamella CLPT is exceeded by that of 5-lamella CLST with up to $18 \% \mathrm{MOE}$ feedstock reduction of all lamellae.

- For $L / d=30$, the bending stiffness of 5-lamella CLPT is exceeded by that of 3-lamella CLST with up to $10 \%$ MOE feedstock reduction of all lamellae.

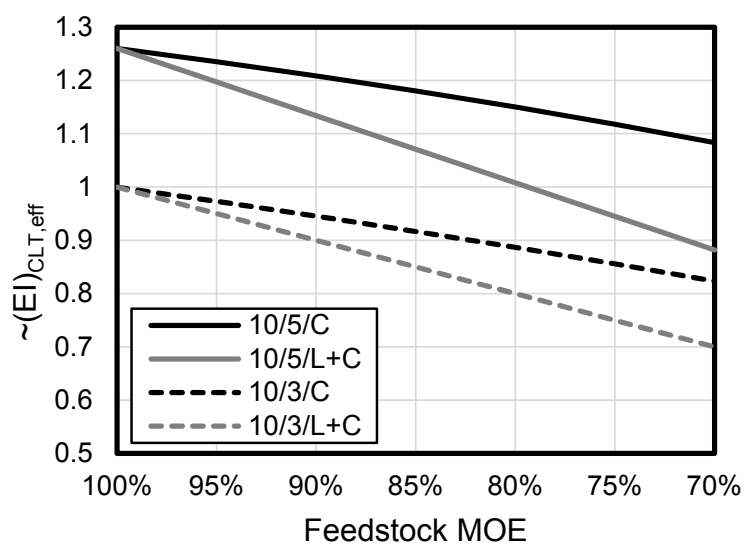

(a)

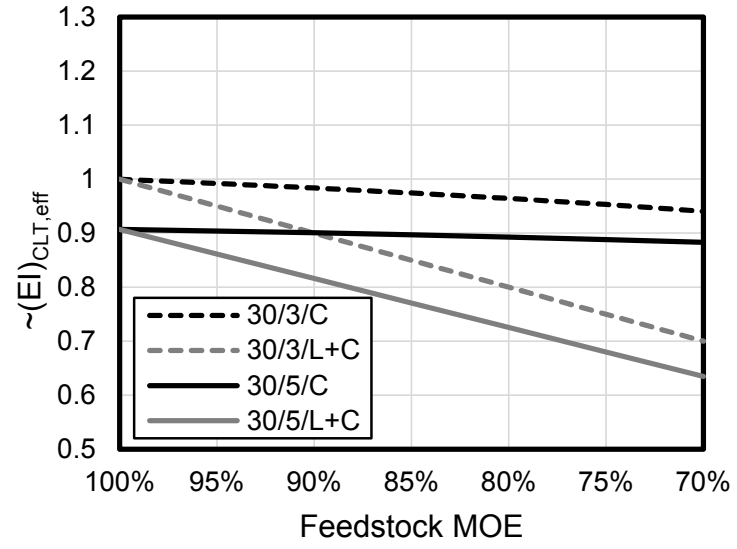

(b)

Figure 6. Normalised bending stiffness $\left(\sim E_{C L T, e f f}\right)$ for 3- and 5-lamella cross-laminated secondary timber with varying feedstock modulus of elasticity (MOE) reductions, of the longitudinal (L) and/or crosswise (C) lamellae, with (a) span-to-depth ratio, $L / d=10$, and (b) $L / d=30$. 
Figure 7 shows the normalised 3- and 5-lamella bending stiffness as surfaces over the range of span-to-depth ratios and reductions in feedstock MOE of the crosswise lamellae. At $L / d<18.5$, a 5-lamella element is always stiffer for a reduction in feedstock MOE of up to $30 \%$, while at $L / d>22$ a 3-lamella element is stiffer. In the zone $18<L / d<22$, CLST with either 3 or 5 lamellae may be stiffer, depending on the reduction of the feedstock MOE.

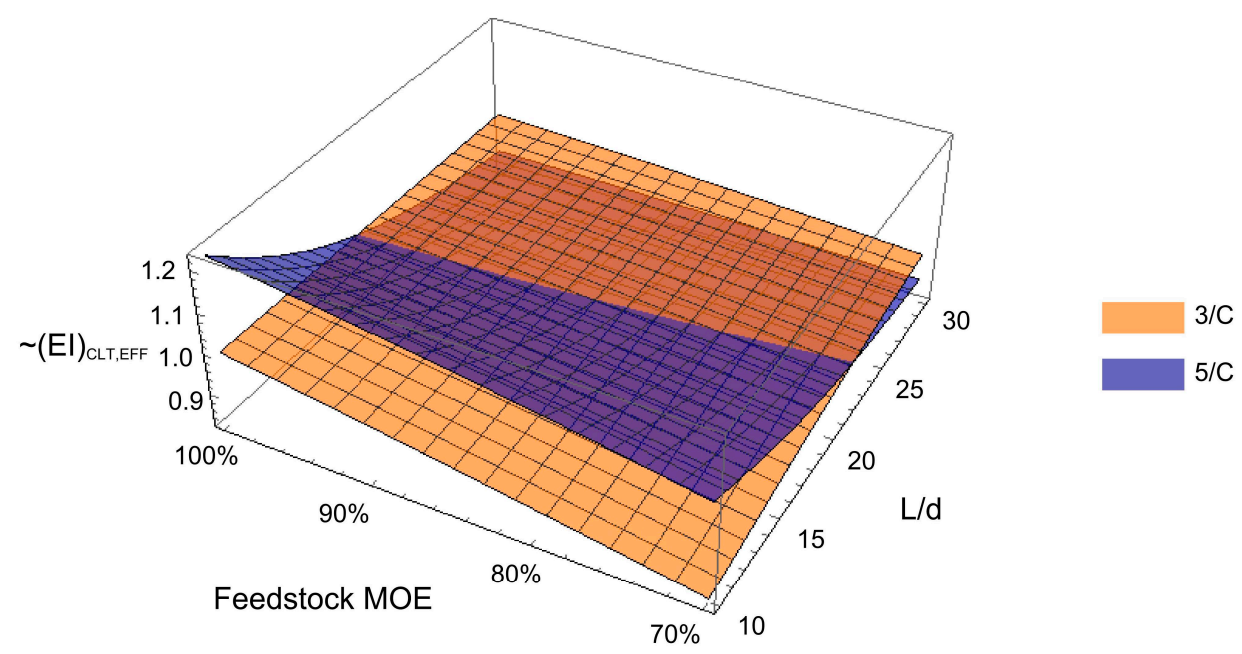

Figure 7. Bending stiffness of 3- and 5-lamella cross-laminated secondary timber elements with reduced crosswise feedstock modulus of elasticity (MOE), as a function of span-to-depth, $L / d$.

\section{Discussion}

\subsection{Implications, Limitations and Recommendations}

Physical production of specimens in the UCL laboratory highlighted no fundamental constraints on the principle of upcycling secondary timber into CLST. Feedstock was easily sourced through existing reuse infrastructure; to support viable CLST manufacturing plants, this would need to develop holistically as a system comprising information about materials soon to emerge from demolition activities, procurement, reclamation and consolidation [16,24]. Although trimming reduced yield considerably, in real-world practice, lamella thickness could be designed to optimise yield from the available feedstock.

The bending MOE and MOR of both CLST and CLPT were influenced by poor quality finger joints and delamination. These are attributable to the limited CLT production capability of the UCL laboratory, and scaling effects that caused a disproportionate impact of finger joints and large defects on mechanical properties. The lower MOR and higher MOE of CLST may be attributable to the greater number of finger joints necessitated by the shorter length of the secondary timber boards; however, greater stiffness and brittleness may also be an effect of ageing [87] and requires further investigation.

In light of these constraints on experimental testing, FEM and MJBT are shown to be effective methods of preliminary research into the effects of a secondary timber feedstock. The FEM indicates that small defects like nail holes and screw holes, up to the concentrations found in a survey of secondary timber, would degrade MOE of CLST in compression, or bending, by less than $6 \%$ compared to a configuration with no defects. It appears that distributed defects are less degrading for the MOE of CLST than concentrated defects, and single large defects have greater impact than many small defects. This implies that attention should be paid to the identification and removal of sections of members that contain large or concentrated defects. This is a simpler process than condemning all members that have small, scattered holes [116], and could be expected to result in a larger yield of useable timber.

Means of establishing the degree of confidence that can be attributed to secondary timber, equivalent to grading procedures for primary timber, will be necessary for its high-value reuse. To address inconclusive current knowledge of the effect of ageing and unknown histories of loading 
and climatic conditions, MJBT was used to assess the suitability of using secondary feedstock that may have a reduced MOE. The MJBT calculations suggest that it may be viable to use secondary timber with a reduced MOE for crosswise lamellae within CLT for compression elements (walls) or bending elements (floors) that have a large span-to-depth ratio without significantly compromising element properties. However, for bending elements with a low span-to-depth ratio, crosswise lamellae with a reduced MOE significantly reduce overall section stiffness. This is due to the quadratic relationship of the element length to the rolling shear of the crosswise lamellae when defining the fastener stiffness $\gamma$.

The MJBT calculations also indicate that for bending elements, the number of lamellae that provides a stiffer overall section is dependent on the span-to-depth ratio. The interaction between the 5-lamella and 3-lamella configurations as a function of span-to-depth ratio provides the opportunity to optimise the specification of CLST based on the structural requirements and geometry of an element, and the resource drivers of a particular project. If material resource efficiency is prioritised (i.e., as much secondary timber is used as possible), then 5-lamella CLST elements with crosswise lamellae feedstock from secondary timber will be more favourable than 3-lamella CLPT. If fabrication resource efficiency is prioritised, then 3-lamella layups may be preferred to 5-lamella.

Arguably, there is good potential to use high-quality CLST containing a limited amount of high-quality secondary timber in the crosswise lamellae as a replacement for CLT in most applications. There are also perhaps three situations where CLST produced entirely from secondary timber feedstock with a reduced MOE may be suitable: (1) specific elements where structural demands are low and a reduction in mechanical properties can be accommodated, such as single-storey buildings, or for external or partition walls which are not considered part of the primary load-bearing or stability structure; (2) specific elements where an increase in element thickness and weight is not critical, such as structures on lower value land where the ratio between gross area and net area is not critical, or where the foundations are inexpensive; and (3) stocky bending elements in scenarios where material efficiency is prioritised over fabrication efficiency, and 5-lamella CLST can be specified as a stiffer alternative to 3-lamella section equivalents.

Currently, BS EN 16351:2015 [70] requires all timber for CLT to be strength graded or tested according to BS EN 14081-1:2016 [47]. Most European CLT production uses C24 graded timber throughout the section, as it is widely available, rather than because it is specified [53]. Thus, high-grade members are employed indiscriminately in lamellae that perform little structural function. Since the majority of CLT is produced for a specific application, it is possible to determine the extent to which feedstock of a lesser grade may be used. The present article applies this in the context of reusing secondary timber for environmental benefits. The findings may also have relevance to normal CLT production with a wider range of harvested timber, in pursuit of potential cost savings and environmental benefits.

\subsection{Further Research}

As a pilot research project, the findings stimulate further research questions to advance this concept towards commercial application through additional laboratory- and pilot-scale experiments and modelling:

- What are the properties and variability of secondary timber feedstock? How can these best be characterised for commercial-scale quality control?

- How does variability in the properties of secondary timber affect the variability of CLST stiffness and strength properties?

- Does physical testing bear out modelled findings on the effectiveness of various CLST formats?

- Is there any difference in the bond strength, dimensional stability, rolling shear behaviour and fire behaviour of CLST and CLPT?

- What quantities of secondary timber are available and useable in CLST, and at what cost relative to conventional CLT? 
- What scale of operation is needed to be commercially viable?

- Can conventional PUR and melamine-urea-formaldehyde adhesives be replaced with a non-toxic biodegradable alternative, or other joining technique (e.g., Brettstapel, friction-welding of wood [117-121]), for a product that is consistent with biological metabolism in a circular economy $[46,122]$ ?

\section{Conclusions}

The construction industry's consumption of raw materials creates environmental degradation, and the GHG emissions associated with producing and delivering building components will need to be reduced to meet legally binding targets. The industry creates significant volumes of waste wood, much of which has residual quality and value that dissipates in conventional waste management processes. Extending the lifespan of timber creates GHG benefits, but this may be of modest significance if it replaces the use of primary timber [123,124]. Greater benefits come about where components' performance is enhanced, such that a secondary resource can perform a duty normally performed by a material of greater environmental impacts [125]. Innovation in component repurposing and upcycling must look for ways to extract greater performance from secondary resources by making it feasible for practitioners to employ them in place of more impact-intensive primary resources. This article makes a preliminary step towards doing so by exploring the use of secondary timber in CLST using complementary methods.

The fabrication process and mechanical properties of CLST were tested in small-scale laboratory experiments, which showed no significant difference between the compression stiffness and strength of CLST and a control. Finite element modelling suggested that typical minor defects in secondary timber have only a small effect on CLST panel stiffness in compression and bending. Mechanically Jointed Beams Theory calculations to examine the potential impacts of secondary timber ageing on CLST panels found that this has little effect on compression stiffness if only the crosswise lamellae are replaced. Since use of secondary timber to make CLST has a more significant effect on bending stiffness, design using CLST will need to consider appropriate combinations of primary and secondary timber for specific structural applications.

More testing is needed to build upon this concept and generate a greater understanding of the characteristics of secondary timber and its properties within CLST. Commercialisation will also require consideration of other issues of sustainability, including the supply of secondary timber, and life-cycle environmental impacts of CLST production in comparison with CLT.

Supplementary Materials: The following are available online at http:/ / www.mdpi.com/2071-1050/10/11/4118/ s1. S1: ABAQUS model geometry.

Author Contributions: Conceptualization, C.M.R. and J.A.S.; Formal analysis, D.B., T.D., E.U. and T.L.; Funding acquisition, C.M.R. and J.A.S.; Investigation, C.M.R., D.B., T.D., E.U. and T.L.; Methodology, C.M.R., D.B., T.D., P.D. and J.A.S.; Project administration, C.M.R.; Supervision, P.D. and J.A.S.; Validation, C.M.R., D.B. and J.A.S.; Visualization, C.M.R., D.B., E.U., T.L. and J.A.S.; Writing-original draft, C.M.R. and D.B.; Writing-review \& editing, C.M.R., P.D. and J.A.S.

Funding: This research was funded by EPSRC, grant number EP/G037698/1, and UCL Centre for Urban Sustainability and Resilience Impact Award. The APC was funded by UCL. Additional support from project collaborators Poplar HARCA and Tower Hamlets Homes is gratefully acknowledged.

Acknowledgments: The authors would like to thank the Remakery Brixton Limited for providing secondary timber used in the experimental work, the UCL laboratory staff, particularly Ian Seaton, and the reviewers for their constructive input.

Conflicts of Interest: The authors declare no conflict of interest. The funders had no role in the design of the study; in the collection, analyses, or interpretation of data; in the writing of the manuscript, and in the decision to publish the results. 


\section{References}

1. Höglmeier, K.; Weber-Blaschke, G.; Richter, K. Potentials for cascading of recovered wood from building deconstruction-A case study for south-east Germany. Resour. Conserv. Recycl. 2013, 78, 81-91. [CrossRef]

2. Kleemann, F.; Lederer, J.; Rechberger, H.; Fellner, J. GIS-based Analysis of Vienna's Material Stock in Buildings. J. Ind. Ecol. 2017, 21, 368-380. [CrossRef]

3. Müller, D.B. Stock dynamics for forecasting material flows-Case study for housing in The Netherlands. Ecol. Econ. 2006, 59, 142-156. [CrossRef]

4. Stahel, W.R. The Product-Life Factor. In An Inquiry into the Nature of Sustainable Societies: The Role of the Private Sector; Orr, S.G., Ed.; FAO: Roma, Italy, 1982; pp. 72-96.

5. Ellen MacArthur Foundation. Towards the Circular Economy. J. Ind. Ecol. 2013, 1, 23-44.

6. BioRegional. Reclaimed Building Materials in the Development of the Thames Gateway; BioRegional: Wallington, UK, 2006.

7. Bergman, R.D.; Falk, R.H.; Salazar, J.; Gu, H.; Napier, T.R.; Meil, J. Life-Cycle Energy and GHG Emissions for New and Recovered Softwood Framing Lumber and Hardwood Flooring Considering End-of-Life Scenarios; United States Department of Agriculture: Madison, WI, USA, 2013.

8. Bergman, R.D.; Gu, H.; Falk, R.H.; Napier, T.R. Using Reclaimed Lumber and Wood Flooring in Construction: Measuring Environmental Impact Using Life-Cycle Inventory Analysis. In Proceedings of the International Convention of Society of Wood Science and Technology and United Nations Economic Commission for Europe-Timber Committee, Geneva, Switzerland, 11-14 October 2010; pp. 1-11.

9. Sirkin, T.; ten Houten, M. The cascade chain. A theory and tool for achieving resource sustainability with applications for product design. Resour. Conserv. Recycl. 1994, 10, 213-276. [CrossRef]

10. Fraanje, P.J. Cascading of pine wood. Resour. Conserv. Recycl. 1997, 19, 21-28. [CrossRef]

11. Husgafvel, R.; Linkosalmi, L.; Hughes, M.; Kanerva, J.; Dahl, O. Forest sector circular economy development in Finland: A regional study on sustainability driven competitive advantage and an assessment of the potential for cascading recovered solid wood. J. Clean. Prod. 2017, 181, 483-497. [CrossRef]

12. Brand, S. How Buildings Learn: What Happens after They're Built; Viking: New York, NY, USA, 1994; ISBN1 0670835153. ISBN2 9780670835157.

13. Durmišević, E. Buildings as Material Banks. In The 3rd International Conference "The Importance of Place"; Popovac, M.R., Idrizbegović-Zgonić, A., Klarić, S., Rustempašić, N., Čausević, A., Eds.; CICOPBH: Sarajevo, Bosnia and Herzegovina, 2015; Volume 2, pp. 139-152.

14. Sassi, P. Designing buildings to close the material resource loop. Proc. ICE-Eng. Sustain. 2004, 163-171. [CrossRef]

15. Falk, R.H.; Maul, D.G.; Cramer, S.M.; Evans, J.; Herian, V. Engineering Properties of Douglas-fir Lumber Reclaimed from Deconstructed Buildings-Research Paper FPL-RP-650; United States Department of Agriculture: Madison, WI, USA, 2008.

16. Rose, C.M.; Stegemann, J.A. From Waste Management to Component Management in the Construction Industry. Sustainability 2018, 10, 229. [CrossRef]

17. Allwood, J.M.; Ashby, M.F.; Gutowski, T.G.; Worrell, E. Material efficiency: A white paper. Resour. Conserv. Recycl. 2011, 55, 362-381. [CrossRef]

18. Defra. Review of the Future Resource Risks Faced by UK Business and an Assessment of Future Viability; Defra: London, UK, 2010.

19. BIS. Low Carbon Construction: Innovation \& Growth Team Final Report; BIS: London, UK, 2010.

20. Giesekam, J.; Barrett, J.; Taylor, P.; Owen, A. The greenhouse gas emissions and mitigation options for materials used in UK construction. Energy Build. 2014, 78, 202-214. [CrossRef]

21. Steele, K.; Hurst, T.; Giesekam, J. Green Construction Board Low Carbon Routemap for the Built Environment: 2015 Routemap Progress - Technical Report; Green Construction Board: London, UK, 2015.

22. Giesekam, J.; Barrett, J.R.; Taylor, P. Construction sector views on low carbon building materials. Build. Res. Inf. 2015, 3218, 1-23. [CrossRef]

23. Papakosta, A.; Sturgis, S. RICS Professional Statement: Whole Life Carbon Assessment for the Built Environment, 1st ed.; RICS: London, UK, 2017.

24. Rose, C.M.; Stegemann, J.A. Characterising Existing Buildings as Material Banks (E-BAMB) to Enable Component Reuse. Proc. Inst. Civ. Eng. Eng. Sustain. 2018, 161, 173-180. [CrossRef] 
25. Jones, K.; Stegemann, J.; Sykes, J.; Winslow, P. Adoption of unconventional approaches in construction: The case of cross-laminated timber. Constr. Build. Mater. 2016, 125, 690-702. [CrossRef]

26. Hairstans, R. Timber 2016 Industry Yearbook; Trada: High Wycombe, UK, 2016; pp. 38-43.

27. Brandner, R.; Flatscher, G.; Ringhofer, A.; Schickhofer, G.; Thiel, A. Cross laminated timber (CLT): Overview and development. Eur. J. Wood Wood Prod. 2016, 74, 331-351. [CrossRef]

28. Concu, G.; De Nicolo, B.; Fragiacomo, M.; Trulli, N.; Valdes, M. Grading of maritime pine from Sardinia (Italy) for use in cross-laminated timber. Proc. Inst. Civ. Eng. Constr. Mater. 2017, 171, 11-21. [CrossRef]

29. Taylor, L. In Touch with Timber; Trada: High Wycombe, UK, 2013; pp. 18-19.

30. BSI. BS EN 14080:2013: Timber Structures—Glued Laminated Timber and Glued Solid Timber-Requirements; BSI Standards Publication: London, UK, 2014.

31. BSI. BS EN 1995-1-1:2004+A2:2014: Eurocode 5: Design of Timber Structures_Part 1-1: General—Common Rules and Rules for Buildings; BSI Standards Publication: London, UK, 2014.

32. Christovasilis, I.P.; Brunetti, M.; Follesa, M.; Nocetti, M.; Vassallo, D. Evaluation of the mechanical properties of cross laminated timber with elementary beam theories. Constr. Build. Mater. 2016, 122, 202-213. [CrossRef]

33. Milner, M. Timber 2017 Industry Yearbook; Trada: High Wycombe, UK, 2017; pp. 90-97.

34. GLA. The London Plan: Draft for Public Consultation; GLA: London, UK, 2017; pp. 1-532.

35. Brunner, P.H. Urban mining a contribution to reindustrializing the city. J. Ind. Ecol. 2011, 15, 339-341. [CrossRef]

36. FAO. State of the World's Forests 2011; FAO: Rome, Italy, 2011.

37. Pöyry. Wood Waste Market in the UK; Pöyry: Banbury, UK, 2009.

38. Tolvik. 2011 Briefing Report: The UK Waste Wood Market; Tolvik: Dursley, UK, 2011.

39. WRAP. Market Situation Report: Realising the Value of Recovered Wood; WRAP: Banbury, UK, 2011.

40. Defra. Wood Waste: A Short Review of Recent Research; Defra: London, UK, 2012.

41. Defra. UK Statistics on Waste; Defra: York, UK, 2016.

42. Gavron, N.; Devenish, T.; Boff, A.; Shah, N.; Copley, T. Designed, Sealed, Delivered: The Contribution of Offsite Manufactured Homes to Solving London's Housing Crisis; Greater London Authority: London, UK, 2017.

43. European Commission. European Resource Efficiency Platform (EREP): Manifesto E Policy Recommendations; European Commission: Brussels, Belgium, 2012; pp. 1-13.

44. European Commission. Towards a Circular Economy: A Zero Waste Programme for Europe; European Commission: Brussels, Belgium, 2014.

45. European Commission. Closing the Loop - An EU Action Plan for the Circular Economy; European Commission: Brussels, Belgium, 2015; Volume 614, p. 21.

46. Campbell, A. Mass Timber in the Circular Economy: Paradigm in Practice? Proc. Inst. Civ. Eng. Eng. Sustain. 2018, 1-12. [CrossRef]

47. BSI. BS EN 14081-1:2016: Timber Structures—Strength Graded Structural Timber with Rectangular Cross Section, Part 1: General Requirements; BSI Standards Publication: London, UK, 2016.

48. BSI. BS EN 338:2016: Structural Timber—Strength Classes; BSI Standards Publication: London, UK, 2016.

49. BSI. BS 4978:2007+A2:2017: Visual Strength Grading of Softwood—Specification; BSI Standards Publication: London, UK, 2017.

50. BSI. BS EN 1912:2012: Structural Timber-Strength Classes-Assignment of Visual Grades and Species; BSI Standards Publication: London, UK, 2013.

51. Brandner, R. Production and Technology of Cross Laminated Timber (CLT): A State-of-the-Art Report. In Proceedings of the European Conference on Cross Laminated Timber (CLT), Graz, Austria, 21-22 May 2013.

52. Espinoza, O.; Buehlmann, U. Cross-Laminated Timber in the USA: Opportunity for Hardwoods? Curr. For. Rep. 2018, 4, 1-12. [CrossRef]

53. Crawford, D.; Hairstans, R.; Smith, R.E. Feasibility of Cross-Laminated Timber Production from UK Sitka spruce. In Focus Solid Timber Solutions, Proceedings of the European Conference on Cross Laminated Timber (CLT), Graz, Austria, 21-22 May 2013; Harris, R., Ringhofer, A., Schickhofer, G., Eds.; The University of Bath: Graz, Austria, 2014; pp. 37-52.

54. Crawford, D.; Hairstans, R.; Smith, S.; Papastravou, P. Viability of cross-laminated timber from UK resources. Proc. ICE Constr. Mater. 2015, 168, 110-120. [CrossRef] 
55. Sikora, K.S.; McPolin, D.O.; Harte, A.M. Effects of the thickness of cross-laminated timber (CLT) panels made from Irish Sitka spruce on mechanical performance in bending and shear. Constr. Build. Mater. 2016, 116, 141-150. [CrossRef]

56. Fragiacomo, M.; Riu, R.; Scotti, R. Can Structural Timber Foster Short Procurement Chains within Mediterranean Forest? A Res. Case Sard. 2015, 6, 107-117.

57. Franke, S. Mechanical Properties of Beech CLT. In Proceedings of the WCTE 2016 World Conference on Timber Engineering, Vienna, Austria, 22-25 August 2016; Eberhardsteiner, J., Winter, W., Fadai, A., Pöll, M., Eds.; Vienna University of Technology, Austria: Vienna, Austria, 2016; pp. 22-25.

58. Aicher, S.; Christian, Z.; Hirsch, M. Rolling shear modulus and strength of beech wood laminations. Holzforschung 2016, 70, 773-781. [CrossRef]

59. Aicher, S.; Hirsch, M.; Christian, Z. Hybrid cross-laminated timber plates with beech wood cross-layers. Constr. Build. Mater. 2016, 124, 1007-1018. [CrossRef]

60. Essoua Essoua, G.G.; Blanchet, P. Cross laminated timber made from large-leaf beech: Production, characterization and testing. In Proceedings of the 6th International Scientific Conference on Hardwood Processing (ISCHP2017), Lahti, Finland, 25-28 September 2017; Möttönen, V., Heinonen, E., Eds.; Natural Resources Institute Finland: Lahti, Finland, 2017; pp. 208-212.

61. Hindman, D.P.; Bouldin, J.C. Mechanical Properties of Southern Pine Cross-Laminated Timber. J. Mater. Civ. Eng. 2015, 27, 1-7. [CrossRef]

62. Sharifnia, H.; Hindman, D.P. Effect of manufacturing parameters on mechanical properties of southern yellow pine cross laminated timbers. Constr. Build. Mater. 2017, 156, 314-320. [CrossRef]

63. Kramer, A.; Barbosa, A.R.; Sinha, A. Viability of Hybrid Poplar in ANSI Approved Cross-Laminated Timber Applications. J. Mater. Civ. Eng. 2014, 26, 06014009. [CrossRef]

64. Mohamadzadeh, M.; Hindman, D. Mechanical Performance of Yellow-Poplar Cross Laminated Timber; Virginia Tech: Blacksburg, VA, USA, 2015.

65. Thomas, R.E.; Buehlmann, U. Using Low-Grade Hardwoods for CLT Production: A Yield Analysis. In Proceedings of the 6th International Scientific Conference on Hardwood Processing (ISCHP2017), Lahti, Finland, 25-28 September 2017; Möttönen, V., Heinonen, E., Eds.; Natural Resources Institute Finland: Lahti, Finland, 2017; pp. 199-206.

66. Wang, Z.; Fu, H.; Chui, Y.; Gong, M. Feasilibity of Using Poplar As Cross Layer To Fabricate Cross-Laminated Timber. In Proceedings of the 13th World Conference on Timber Engineering, Quebec City, QC, Canada, 10-14 August 2014.

67. Liao, Y.; Tu, D.; Zhou, J.; Zhou, H.; Yun, H.; Gu, J.; Hu, C. Feasibility of manufacturing cross-laminated timber using fast-grown small diameter eucalyptus lumbers. Constr. Build. Mater. 2017, 132, 508-515. [CrossRef]

68. Okabe, M.; Yasumura, M.; Kobayashi, K.; Fujita, K. Prediction of bending stiffness and moment carrying capacity of sugi cross-laminated timber. J. Wood Sci. 2014, 60, 49-58. [CrossRef]

69. Vloysky, R.P. International Beams Announces Innovative Wood Products Manufacturing Facility Construction in Dothan, Alabama; International Beams: Baton Rouge, LA, USA, 2017.

70. BSI. BS EN 16351:2015: Timber Structures_Cross Laminated Timber-Requirements; BSI Standards Publication: London, UK, 2015; pp. 1-103.

71. Geldermans, R.J. Cradle-to-Cradibility: Two Material Cycles and the Challenges of Closed Loops in Construction; TU Delft/Leiden University: Leiden, The Netherlands, 2009.

72. Sakaguchi, D. Potential for Cascading Wood From Building; Aalto University: Espoo, Finland, 2014.

73. Bergsagel, D. Disassembling Detroit: How deconstructing the post-industrial Rust Belt could give structural timber another life. Struct. Eng. 2016, 94, 12-19.

74. Kremer, P.D.; Symmons, M.A. Mass timber construction as an alternative to concrete and steel in the Australia building industry: A PESTEL evaluation of the potential. Int. Wood Prod. J. 2015, 6, 138-147. [CrossRef]

75. Smith, R.E. Interlocking Cross-Laminated Timber: Alternative use of waste wood in design and construction. In Proceedings of the BTES Conference 2011-Convergence and Confluence, Toronto, ON, Canada, 4-7 August 2011; Hui, V., Meyer Boake, T., Eds.; Building Technology Educators' Society: Toronto, ON, Canada, 2011.

76. Wilson, D.E. Structural Properties of ICLT Wall Panels Composed of Beetle Killed Wood; Brigham Young University: Provo, UT, USA, 2012. 
77. Ridley-Ellis, D.; Stapel, P.; Bano, V. Strength grading of sawn timber in Europe: An explanation for engineers and researchers. Eur. J. Wood Wood Prod. 2016, 74, 291-306. [CrossRef]

78. Nilsson, T.; Rowell, R. Historical wood-Structure and properties. J. Cult. Herit. 2012, 13, S5-S9. [CrossRef]

79. Kohara, J.; Okamoto, H. Studies of Japanese old timbers. Sci. Rep Saikyo Univ. 1955, 7, 9-20. [CrossRef]

80. Nakao, T.; Tanaka, C.; Takahashi, A.; Okano, T.; Nishimura, H. Short Note Long-Term Changes in Degree of Crystallinity of Wood Cellulose. Holzforschung 1989, 43, 419-420. [CrossRef]

81. Lionetto, F.; Del Sole, R.; Cannoletta, D.; Vasapollo, G.; Maffezzoli, A. Monitoring wood degradation during weathering by cellulose crystallinity. Materials 2012, 5, 1910-1922. [CrossRef]

82. Cavalli, A.; Cibecchini, D.; Togni, M.; Sousa, H.S. A review on the mechanical properties of aged wood and salvaged timber. Constr. Build. Mater. 2016, 114, 681-687. [CrossRef]

83. Kránitz, K.; Sonderegger, W.; Bues, C.T.; Niemz, P. Effects of aging on wood: A literature review. Wood Sci. Technol. 2016, 50, 7-22. [CrossRef]

84. Froidevaux, J.; Navi, P. Aging law of spruce wood. Wood Mater. Sci. Eng. 2013, 8, 46-52. [CrossRef]

85. Sonderegger, W.; Kránitz, K.; Bues, C.T.; Niemz, P. Aging effects on physical and mechanical properties of spruce, fir and oak wood. J. Cult. Herit. 2015, 16, 883-889. [CrossRef]

86. Holzer, S.M.; Loferski, J.R.; Dillard, D.A. A review of creep in wood: Concepts relevant to develop long-term behavior predictions for wood structures. Wood Fiber Sci. 1989, 21, 376-392.

87. Attar-Hassan, G. The Effect of Ageing on the Mechanical Properties of Eastern White Pine. Bull. Assoc. Preserv. Technol. 1976, 8, 64-73. [CrossRef]

88. Fridley, K.J.; Hunt, M.O.; Senft, J.F. Historical perspective of duration-of-load concepts. For. Prod. J. 1995, $45,1-6$.

89. Hoffmeyer, P. Strength under long-term loading. In Timber Engineering; Thelandersson, S., Larsen, H.J., Eds.; John Wiley \& Sons: Chichester, UK, 2003; pp. 131-152. ISBN 9780470844694.

90. Hoffmeyer, P.; Sørensen, J.D. Duration of load revisited. Wood Sci. Technol. 2007, 41, 687-711. [CrossRef]

91. Wood, L.W. Relation of Strength of Wood to Duration of Load; Forest Products Laboratory: Madison, WI, USA, 1960.

92. Dinwoodie, J.M. Timber-A review of the structure-mechanical property relationship. J. Microsc. 1975, 104, 3-32. [CrossRef]

93. Falk, R.H.; Patton-Mallory, M.; McDonald, K.A. Nondestructive testing of wood products and structures: State-of-the-art and research needs. In Nondestructive Testing and Evaluation for Manufacturing and Construction; doe Reis, H.L.M., Ed.; Hemisphere Publishing Corp.: Champaign, IL, USA, 1990; Volume 24, pp. 137-147.

94. Falk, R.H. The properties of lumber and timber recycled from deconstructed buildings. In Ptec 99—Pacific Timber Engineering Conference; Walford, G.B., Gaunt, D.J., Eds.; Forest Research Bulletin: Rotorua, New Zealand, 1999; pp. 255-257.

95. Williams, J.M.; Fridley, K.J.; Cofer, W.F.; Falk, R.H. Failure modeling of sawn lumber with a fastener hole. Finite Elem. Anal. Des. 2000, 36, 83-98. [CrossRef]

96. Fridley, K.J.; Mitchell, J.B.; Hunt, M.O.; Senft, J.F. Effect of 85 years of service on mechanical properties of timber roof members. Part 1. Experimental observations. For. Prod. J. 1996, 46, 72-78.

97. Falk, R.H.; Cramer, S.; Evans, J. Framing lumber from building removal: How do we best utilize this untapped structural resource? For. Prod. J. 2012, 62, 492-499. [CrossRef]

98. Falk, R.H.; Green, D.; Rammer, D.; Lantz, S.C. Engineering Evaluation of 55-Year-Old Timber from an Industrial Military Building. For. Prod. J. 2000, 50, 71-76.

99. Falk, R.H. Wood-Framed Building Deconstruction: A Source of Lumber for Construction? For. Prod. J. 2002, 52, 8-15.

100. Falk, R.H.; Green, D.; Lantz, S.C. Evaluation of lumber recycled from an industrial military building. For. Prod. J. 1999, 49, 49-55.

101. Falk, R.H.; DeVisser, D.; Plume, G.R.; Fridley, K.J. Effect of drilled holes on the bending strength of large dimension Douglas-fir lumber. For. Prod. J. 2003, 53, 55-60.

102. Falk, R.H.; Green, D.W. Stress Grading of Recycled Lumber and Timber. In Structures Congress: Structural Engineering in the 21st Century; American Society of Civil Engineers: Reston, VA, USA, 1999; pp. 650-653.

103. Janowiak, J.J.; Falk, R.H.; Gething, B.A.; Tsirigotis, J.A. Mechanical performance of nail-laminated posts manufactured from reclaimed chromated copper arsenate-treated decking lumber. For. Prod. J. 2014, 64, 55-63. [CrossRef] 
104. Falk, R.H.; DeVisser, D.; Cook, S.; Stansbury, D. Effect of damage on the grade yield of recycled lumber. For. Prod. J. 1999, 49, 71-79.

105. Janowiak, J.J.; Falk, R.H.; Kimmel, J. Feasibility of Producing Value-Added Wood Products from Reclaimed Hemlock Lumber; United States Department of Agriculture: Madison, WI, USA, 2007.

106. Janowiak, J.J.; Falk, R.H.; Beakler, B.W.; Lampo, R.G.; Napier, T.R. Remilling of salvaged wood siding coated with lead-based paint. Part I. Lead exposure. For. Prod. J. 2005, 55, 76-80.

107. Remakery Brixton Ltd. Available online: http:/ / remakery.org/ (accessed on 6 June 2018).

108. BSI. BS EN 13183-1:2002: Moisture Content of a Piece of Sawn Timber —Part 1: Determination by Oven Dry Method; BSI Standards Publication: London, UK, 2007.

109. Stora Enso. European Technical Assessment ETA-14/0349 of 02.10.2014; Stora Enso: Vienna, Austria, 2014.

110. BSI. BS EN 408:2010+A1:2012: Timber Structures—Structural Timber and Glued Laminated Timber-Determination of Some Physical and Mechanical Properties; BSI Standards Publication: London, UK, 2012.

111. Arya, C. Design of Structural Elements: Concrete, Steelwork, Masonry and Timber Designs to British Standards and Eurocodes, 3rd ed.; Taylor \& Francis: Abingdon, UK, 2009; ISBN 9780203926505.

112. Carlberg, J.; Toyib, B. Finite Element Modelling of Interlaminar Slip in Stress-Laminated Timber Decks-Friction Interaction Modelling Using Abaqus; Chalmers University of Technology: Gothenburg, Swiden, 2012.

113. Baño, V.; Godoy, D.; Vega, A. Experimental and Numerical Evaluation of Cross-Laminated Timber (CLT) Panels Produced with Pine Timber from Thinnings in Uruguay. In Proceedings of the World Conference on Timber Engineering (WCTE 2016), Vienna, Austria, 22-25 August 2016; pp. 1-8.

114. Domone, P.L.J.; Illston, J.M. Construction Materials: Their Nature and Behaviour, 4th ed.; CRC Press: Boca Raton, FL, USA, 2010; ISBN 0-415-46515-X.

115. Stoeckel, F.; Konnerth, J.; Gindl-Altmutter, W. Mechanical properties of adhesives for bonding wood-A review. Int. J. Adhes. Adhes. 2013, 45, 32-41. [CrossRef]

116. Brol, J.; Dawczy, S.; Adamczyk, K. Possibilities of timber structural members reuse. In Proceedings of the 3rd International Conference on Structural Health Assessment of Timber Structures, Wroclaw, Poland, 9-11 September 2015; pp. 1-7.

117. Stamm, B.; Natterer, J.; Navi, P. Joining of wood layers by friction welding. J. Adhes. Sci. Technol. 2005, 19, 1129-1139. [CrossRef]

118. Hahn, B.; Vallée, T.; Stamm, B.; Weinand, Y. Moment resisting connections composed of friction-welded spruce boards: Experimental investigations and numerical strength prediction. Eur. J. Wood Wood Prod. 2014, 72, 229-241. [CrossRef]

119. Buck, D.; Wang, X.A.; Hagman, O.; Gustafsson, A. Comparison of different assembling techniques regarding cost, durability, and ecology-A survey of multi-layer wooden panel assembly load-bearing construction elements. BioResources 2015, 10, 8378-8396. [CrossRef]

120. Wójcik, M.; Strumiłło, J. Behaviour-based Wood Connection as a Base for New Tectonics; Dublin Institute of Technology: Dublin, Ireland, 2014; pp. 170-184.

121. Ramage, M.H.; Burridge, H.; Busse-Wicher, M.; Fereday, G.; Reynolds, T.; Shah, D.U.; Wu, G.; Yu, L.; Fleming, P.; Densley-Tingley, D.; et al. The wood from the trees: The use of timber in construction. Renew. Sustain. Energy Rev. 2017, 68, 333-359. [CrossRef]

122. McDonough, W.; Braungart, M. Cradle to Cradle: Remaking the Way We Make Things, 1st ed.; North Point Press: New York, NY, USA, 2002; ISBN 0865475873.

123. Sathre, R.; Gustavsson, L. Energy and carbon balances of wood cascade chains. Resour. Conserv. Recycl. 2006, 47, 332-355. [CrossRef]

124. Werner, F.; Taverna, R.; Hofer, P.; Richter, K. Greenhouse gas dynamics of an increased use of wood in buildings in Switzerland. Clim. Chang. 2006, 74, 319-347. [CrossRef]

125. Geyer, R.; Kuczenski, B.; Zink, T.; Henderson, A. Common Misconceptions about Recycling. J. Ind. Ecol. 2016, 20, 1010-1017. [CrossRef]

(C) 2018 by the authors. Licensee MDPI, Basel, Switzerland. This article is an open access article distributed under the terms and conditions of the Creative Commons Attribution (CC BY) license (http:/ / creativecommons.org/licenses/by/4.0/). 